\title{
Nitrogen fixation by subterranean and white clovers in dryland cocksfoot pastures
}

\author{
R.J. LUCAS, M.C. SMITH, P. JARVIS, A. MILLS and D.J. MOOT \\ Faculty of Agriculture and Life Sciences, Lincoln University, Lincoln 7647, Lincoln \\ Derrick.Moot@lincoln.ac.nz
}

\begin{abstract}
The amount of nitrogen $(\mathrm{N})$ in clover dry matter (DM) herbage derived from $\mathrm{N}$ fixation in subterranean or white clover was estimated using the ${ }^{15} \mathrm{~N}$ enrichment technique in a dryland grazing experiment at Lincoln University. Clovers were established in separate mixed swards with cocksfoot in February 2002. Nitrogen fixation measurements were made between November 2002 and December 2005. Both clovers fixed $28 \pm$ $0.7 \mathrm{~kg} \mathrm{~N} / \mathrm{t}$ clover $\mathrm{DM}\left(\mathrm{R}^{2}=0.96\right)$. Using the $28 \mathrm{~kg} \mathrm{~N} / \mathrm{t}$ DM reported here and previously published clover yields from the 'MaxClover' experiment in Years 1-7, $\mathrm{N}$ fixation averaged $81 \mathrm{~kg} \mathrm{~N} / \mathrm{ha} / \mathrm{yr}$ (range: $41-106 \mathrm{~kg}$ $\mathrm{N} / \mathrm{ha} / \mathrm{yr}$ ) from subterranean clover and $46 \mathrm{~kg} \mathrm{~N} / \mathrm{ha} / \mathrm{yr}$ (range: $18-90 \mathrm{~kg} \mathrm{~N} / \mathrm{ha} / \mathrm{yr}$ ) from white clover. Annually, total $\mathrm{N}$ fixed by subterranean clover exceeded that from white clover in 4 of the 7 years.
\end{abstract}

Keywords: Dactylis glomerata, Trifolium repens, $T$. subterraneum

\section{Introduction}

The primary contribution of legumes in pastoral systems is the nitrogen they add through biological fixation. The superior nutritive value of some pasture legume species within genera such as Medicago and Trifolium provide a valuable added bonus. Pioneers in New Zealand agricultural research such as Levy, Sears and Walker stressed the importance of $\mathrm{N}$ fixation by legumes over many decades. The increasing use of $\mathrm{N}$ fertilisers on dairy pastures in particular has encouraged debate and research into the biological productivity and economics of fertiliser $\mathrm{N}$ versus that derived from biological fixation. The energetic efficiency of $\mathrm{N}$ fixation by white clover compared with $\mathrm{N}$ fertilisers has also been emphasised for many years (Walker 1996).

It is important that farmers are well versed in legume agronomy. The need to maximise legume content of pastures is supported by estimates of the amount of $\mathrm{N}$ fixed per tonne of legume herbage dry matter (DM) grown. The reported figure of $25 \mathrm{~kg} \mathrm{~N}$ fixed/t legume DM grown (Peoples \& Baldock 2001) can be converted to $\mathrm{kg}$ urea fertiliser equivalents and to the cost/ha of its application. Hence, this paper reports results in terms of $\mathrm{kg} \mathrm{N}$ fixed/t legume DM produced.

Nitrogen fixation studies in New Zealand have usually focused on perennial ryegrass (Lolium perenne)/white clover (Trifolium repens) pastures in moist environments. For example, Widdup et al. (2001) showed that both white and Caucasian (T. ambiguum) clovers fixed $26 \mathrm{~kg} \mathrm{~N} / \mathrm{t}$ clover DM in irrigated perennial ryegrass pastures in Canterbury.

Cocksfoot is a persistent grass in summer-dry environments where its competitive ability often results in pastures with few weeds and low clover content. This leads to low productivity because of minimal $\mathrm{N}$ inputs from clovers and $\mathrm{N}$ deficient cocksfoot herbage with low grazing preference (Edwards et al. 1993). The 'MaxClover' dryland grazing experiment (Mills et al. 2008a) was designed to identify clover species which could survive in mixtures with cocksfoot and also fix sufficient $\mathrm{N}$ to increase the productivity of the grassbased pastures.

The area used for the dryland 'MaxClover' cocksfoot grazing experiment is adjacent to the irrigated site reported by Widdup et al. (2001). In contrast to that irrigated ryegrass experiment this dryland grazing experiment has cocksfoot as the dominant grass and compares an annual with a perennial clover. Both studies had similar soils, climate, and used 'Grasslands Demand' white clover. Additionally, both experiments were rotationally grazed by young sheep and the ${ }^{15} \mathrm{~N}$ studies were conducted on young pastures for the first 2 or 3 years using monthly pasture samples taken from exclosure cages. The aim of this paper is to quantify $\mathrm{N}$ fixation by subterranean clover (T. subterraneum) and white clover in these cocksfoot-based pastures.

\section{Materials and Methods Experimental}

The 'MaxClover' pasture experiment was sown on 18 February 2002. Full experimental details of the six treatments and management have been published previously (Mills et al. 2008a). This paper focuses on the 'Vision' cocksfoot-based pastures established with 'Grasslands Demand' white clover $(\mathrm{CF} / \mathrm{Wc})$ or late flowering 'Denmark' subterranean clover $(\mathrm{CF} / \mathrm{Sub})$, sown into a medium fertility (pH 6.1, Olsen P 14, K 11, S 11) Templeton silt loam soil (Cox 1978). Additional fertiliser was applied during the experiment to maintain fertility as required following soil tests. 
Importantly, DM and $\mathrm{N}$ yields presented here are not directly comparable to previously published data. At times DM production was limited due to drought, temperature or subterranean clover being absent in summer. Thus, the number of replicates varied as plots with insufficient material were excluded from calculation of treatment means and sometimes ${ }^{15} \mathrm{~N}$ values were unreplicated.

\section{Environmental conditions}

Rainfall and Penman potential evapotranspiration (PET) during the measurement period are shown in Fig. 1. Long-term mean annual rainfall (1975-2002) is $624 \mathrm{~mm}$ which is evenly distributed throughout the year $(\sim 52 \mathrm{~mm} / \mathrm{month})$. Long-term PET is $1025 \mathrm{~mm} /$ $\mathrm{yr}$ and is lowest in June $(30 \mathrm{~mm} / \mathrm{month})$ and highest in December/January ( $145 \mathrm{~mm} /$ month$)$.

\section{Measurements}

Nitrogen fixation was estimated using the $\mathrm{N}$ enrichment method (Ledgard et al. 1985). Areas of the sward were cut to $25 \mathrm{~mm}$ and labelled ammonium sulphate (60 atoms $\%{ }^{15} \mathrm{~N}$ ) at $0.05 \mathrm{~g} \mathrm{~N} / \mathrm{m}^{2}$ was mixed in $1 \mathrm{~L}$ of water and applied to randomly selected areas $\left(0.8 \mathrm{~m}^{2}\right)$. The ${ }^{15} \mathrm{~N}$ solution was washed from the foliage with $0.8 \mathrm{~L}$ water. Exclosure cages were placed over treated areas to exclude grazing sheep.

A total of 34 rotations, of 20-90 d duration, occurred over the 3 years. For the $\mathrm{CF} / \mathrm{Wc}$ pastures ${ }^{15} \mathrm{~N}$ was applied at the start of 27 of those rotations compared with 22 rotations for the $\mathrm{CF} / \mathrm{Sub}$ pastures. Here, only data collected when sown clover was present are used. This was in all 27 regrowth periods for $\mathrm{CF} / \mathrm{Wc}$ pastures and 17 of the 22 regrowth cycles for the $\mathrm{CF} / \mathrm{Sub}$ pastures. At the end of each regrowth period a $0.2 \mathrm{~m}^{2}$ area from within the ${ }^{15} \mathrm{~N}$ treated exclosure cage was cut to a residual height of $25 \mathrm{~mm}$ with hand-shears. Subsamples were taken and sorted into sown grass, sown legume, unsown species and dead material fractions for DM yield and botanical composition. Samples of the sown clovers and sown grass were ground to pass through a $1 \mathrm{~mm}$ sieve and used for ${ }^{15} \mathrm{~N}$ and $\% \mathrm{~N}$ analyses using a mass spectrometer (Anco 20-20 stable isotope analyser) at Lincoln University.

Table 1 Nitrogen concentration (\% of DM) of subterranean (Sub) and white clover in dryland cocksfoot pastures established at Lincoln University, Canterbury on nine harvest dates when full data sets (4 replicates) of each treatment were available.

\begin{tabular}{lccccc}
\hline Harvest Date & Sub & White & Mean & SEM & P \\
\hline $21 / 11 / 2002$ & 3.3 & 4.9 & 4.1 & 0.19 & $* \star$ \\
$11 / 12 / 2002$ & 3.1 & 4.5 & 3.8 & 0.18 & $*$ \\
$27 / 08 / 2003$ & 4.5 & 4.7 & 4.6 & 0.05 & NS \\
$6 / 10 / 2003$ & 3.6 & 4.2 & 3.9 & 0.06 & $* \star$ \\
$4 / 11 / 2003$ & 3.2 & 3.5 & 3.4 & 0.11 & NS \\
$5 / 10 / 2004$ & 4.4 & 4.6 & 4.5 & 0.08 & NS \\
$30 / 11 / 2004$ & 3.3 & 3.6 & 3.5 & 0.18 & NS \\
$12 / 10 / 2005$ & 4.4 & 4.4 & 4.4 & 0.15 & NS \\
$10 / 11 / 2005$ & 4.0 & 4.6 & 4.3 & 0.10 & $*$ \\
\hline
\end{tabular}

Note: levels of significance are: NS $=$ non significant; ${ }^{*}=$ $\mathrm{P}<0.05 ;{ }^{*}=\mathrm{P}<0.01$

Figure 1 Monthly rainfall and Penman potential evapotranspiration (PET) in Years 1-4 from the Broadfields meteorological station located $2 \mathrm{~km}$ north of the 'MaxClover' grazing experiment at Lincoln University, Canterbury.

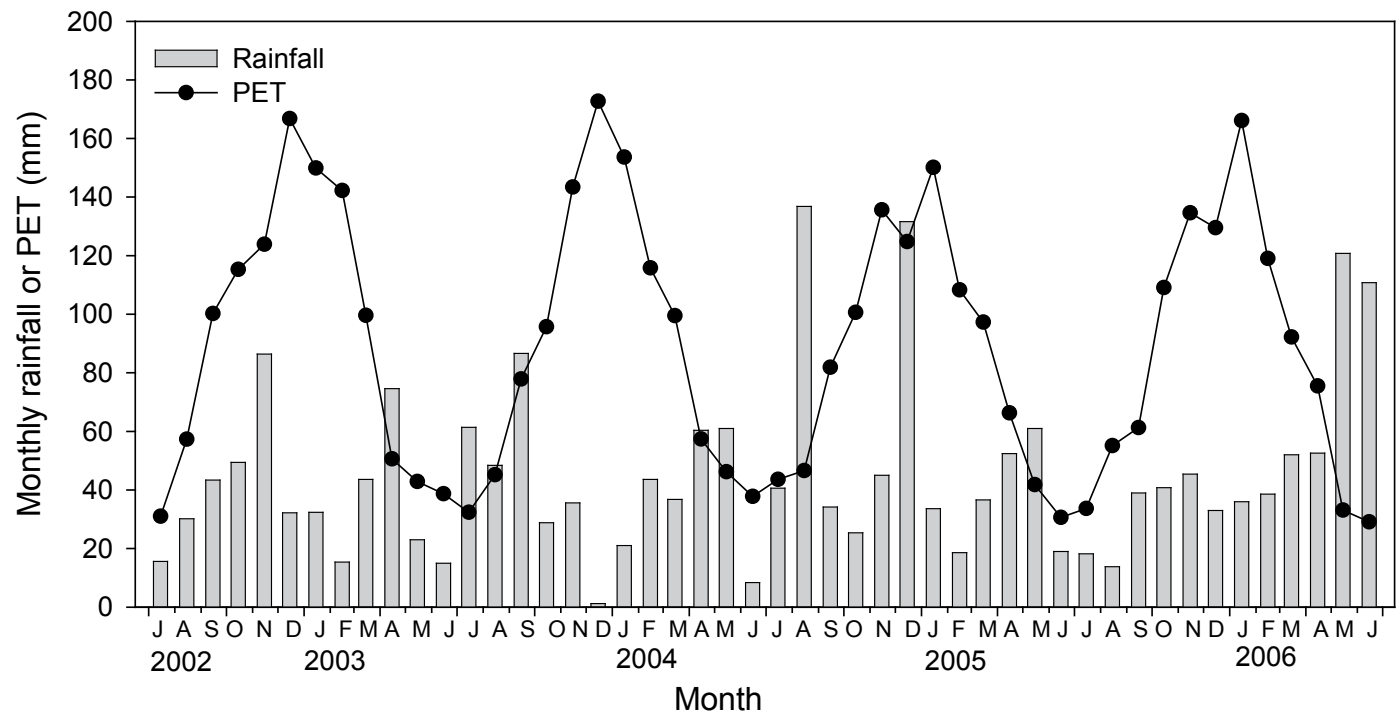


Figure 2 Clover nitrogen yield ( $\mathrm{kg} \mathrm{N} / \mathrm{ha}$ ) from soil (soil $\mathrm{N}$ ) and air (fixed $\mathrm{N}$ ) for subterranean (Sub) and white clovers within dryland cocksfoot-based pastures at the 'MaxClover' grazing experiment at Lincoln University, Canterbury in (a) 2002/2003, (b) $2003 / 2004$, (c) 2004/2005 and (d) 2005/2006 growing seasons. Dashed lines indicate the end of each growing season. Four replicates of data were available at nine harvest dates. At three of these harvests differences were observed. Levels of significance are: ${ }^{*}=\mathrm{P}<0.05$ and ${ }^{\star *}=\mathrm{P}<0.01$
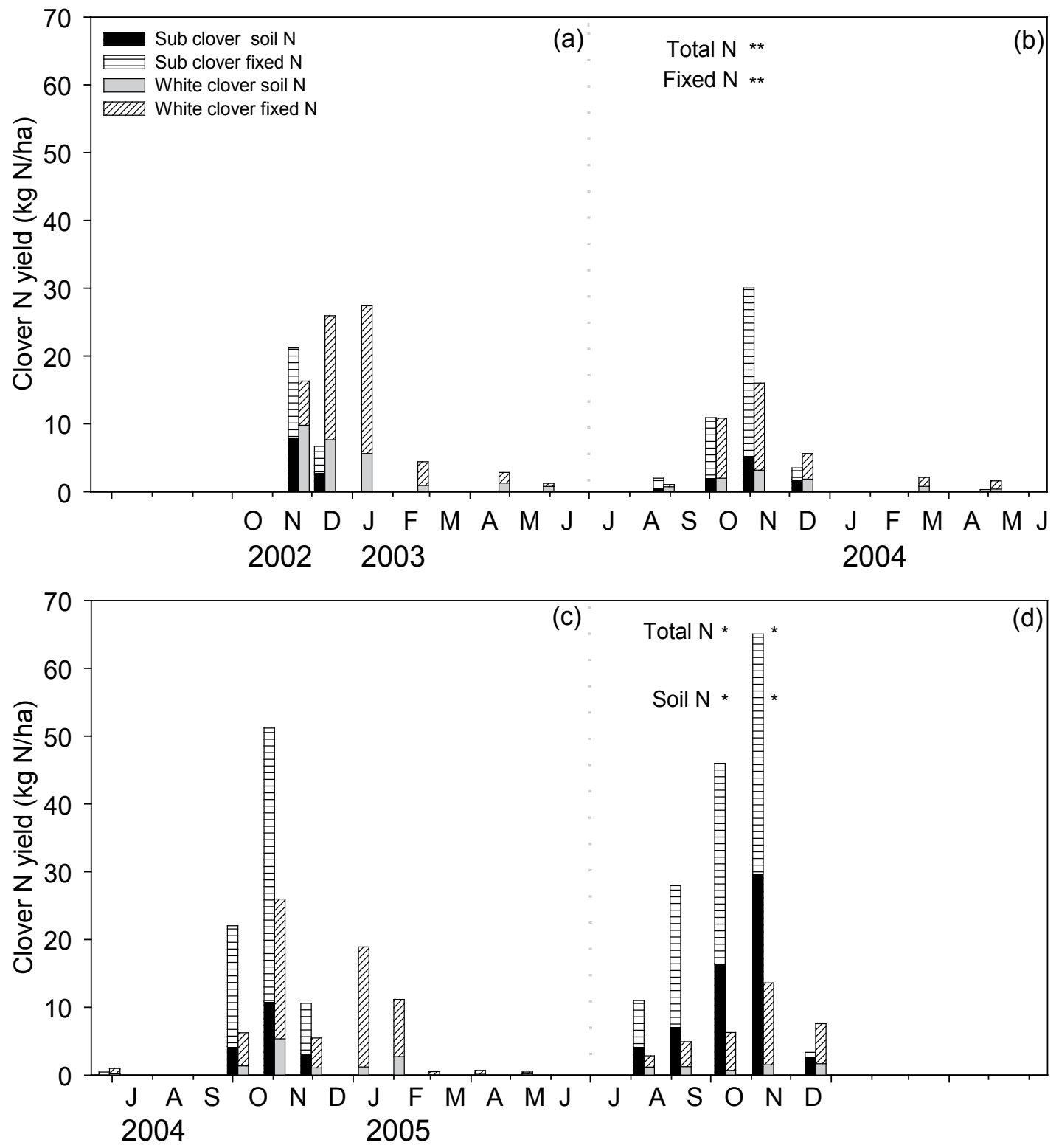

Harvest date

\section{Calculations}

The proportion (\%) of $\mathrm{N}$ fixed by the clovers from atmospheric $\mathrm{N}_{2}\left(\mathrm{~N}_{\text {fix }}\right)$ was calculated using Equation 1:

Equation $1 \quad \mathrm{~N}_{\text {fix }}=100 \times$ x (atoms $\%{ }^{15} \mathrm{~N}_{\text {grass }}-$ atoms $\left.\%{ }^{15} \mathrm{~N}_{\text {clover }}\right) /\left(\right.$ atoms $\left.\%{ }^{15} \mathrm{~N}_{\text {grass }}-\mathrm{B}\right)$

where $\mathrm{B}=0.3663$, which is the atoms $\%{ }^{15} \mathrm{~N}$ of atmospheric $\mathrm{N}_{2}$ (Widdup et al. 2001).
The amount of Fixed N (kg N/ha) in the cut clover herbage was then given by Equation 2:

Equation 2 Fixed $\mathrm{N}=$ clover DM (kg/ha) $\mathrm{x}$ clover $\% \mathrm{~N} / 100 \times \mathrm{N}_{\text {fix }} / 100$

\section{Statistical analysis}

When data for all four replicates of the two treatments 
Table 2 Estimated annual biological $\mathrm{N}$ fixation ( $\mathrm{kg} \mathrm{N} / \mathrm{ha}$ ) from white and subterranean (Sub) clovers grown in cocksfoot pastures from Year 1 (2002/03) to Year 7 (2008/09). There were four replicates of sown clover DM data for Years 1 and 2 and six replicates of data for Years 3-7 of the 'MaxClover' grazing experiment (Mills et al. 2008a; Mills \& Moot 2010, this volume) at Lincoln University, Canterbury, using the $28 \mathrm{~kg} \mathrm{~N} / \mathrm{t}$ clover DM reported in Fig. 3.

\begin{tabular}{|c|c|c|c|c|c|c|c|}
\hline & Year & & & & & & \\
\hline Species & $02 / 03$ & $03 / 04$ & $04 / 05$ & $05 / 06$ & $06 / 07$ & $07 / 08$ & $08 / 09$ \\
\hline White clover & 90 & 25 & 73 & 24 & 55 & 36 & 18 \\
\hline Sub clover & 106 & 41 & 90 & 104 & 44 & 97 & 82 \\
\hline Mean & 98 & 33 & 81 & 64 & 50 & 67 & 50 \\
\hline SEM & 3.8 & 1.8 & 9.7 & 5.9 & 6.6 & 10.8 & 6.1 \\
\hline $\mathrm{P}$ & NS & $\star \star$ & NS & $\star \star \star *$ & NS & $\star \star$ & $\star \star \star *$ \\
\hline
\end{tabular}

Note: levels of significance are: NS = non significant; ${ }^{\star \star}=\mathrm{P}<0.01 ;{ }^{\star \star \star}=\mathrm{P}<0.001$.

(white or subterranean clover) were available (nine harvest dates) data were analysed by ANOVA in Genstat 12.0 (Lawes Agricultural Trust, VSN Ltd.). When significant, Fisher's protected least significant difference (LSD) test was used to separate treatment means. At other times data were not analysed because i) only one of the clover species was present or ii) data were unbalanced because of insufficient clover material for analysis in one or more replicates.

Linear regression, forced through the origin, was used to determine the relationship between biological $\mathrm{N}$ fixation (fixed N, $\mathrm{kg} \mathrm{N} / \mathrm{ha}$ ) and clover yield ( $\mathrm{kg} \mathrm{DM} / \mathrm{ha}$ ) for both clover species across all harvests where fixed $\mathrm{N}$ estimates were available. Slopes were analysed by ANOVA to compare biological $\mathrm{N}$ fixation in the two species.

\section{Results and Discussion}

Subterranean and white clover had similar N concentrations $(\mathrm{N} \%)$ at three of the nine harvest dates analysed. At the other six harvests the $\mathrm{N} \%$ of white clover was greater than that of subterranean clover (Table 1). This is likely to be a result of senescing subterranean clover leaves in late spring and/or a higher proportion of stem material compared with white clover. The proportion of fixed $\mathrm{N}$ in herbage was similar (Fig. 2) for both white and subterranean clovers at six of the nine harvests analysed (average $=71 \%$ ). Both clovers fixed $28 \pm 0.66 \mathrm{~kg} \mathrm{~N} / \mathrm{t}$ clover herbage in these dryland cocksfoot dominant pastures (Fig. 3). Thus, differences in fixed $\mathrm{N}$ were directly related to clover yield.

Up to a point the two clovers were complementary. Subterranean clover exploited its greater cool season growth potential in early spring to provide pastures with high legume content during September/October and, if the soil moisture content was not limiting, through into November (Mills et al. 2008a). White clover, after a slower start in spring, contributed high quality feed in December and later in summer when soil moisture
Figure 3 Fixed nitrogen ( $\mathrm{kg} \mathrm{N} / \mathrm{ha}$ ) against clover yield ( $\mathrm{kg} \mathrm{DM} / \mathrm{ha})$ for white $(n=27)$ and subterranean $(n=17)$ clovers grown in dryland cocksfoot based pastures in the 'MaxClover' grazing experiment at Lincoln University, New Zealand from 2002 to 2005.

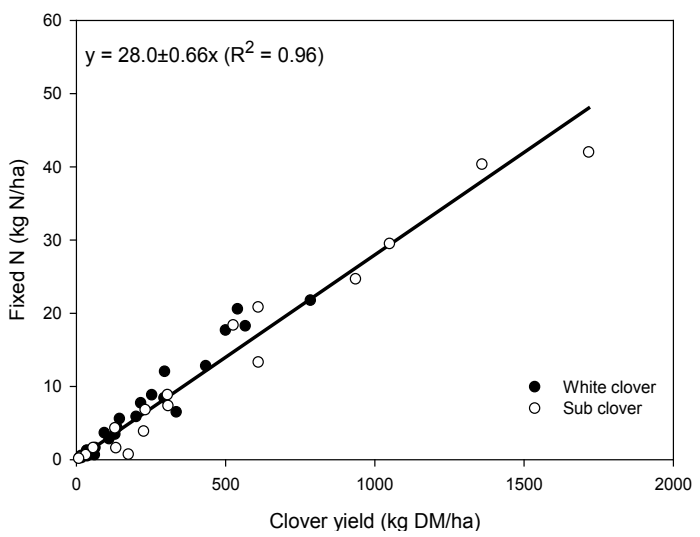

was available. The greater competitive ability of white clover in its first year (sown February 2002) while its tap roots were present (Brock et al. 2000) is illustrated in Fig. 2a where it was productive from November 2002 to February 2003, despite below average summer rainfall and high evapotranspiration (Fig. 1). The white clover production in December/January 2004/2005 (Fig. 2c) came after $132 \mathrm{~mm}$ rain in December while it was much less productive in the summer of 2003/2004 when there was only $1 \mathrm{~mm}$ of rainfall in December (Figs. $1 \& 2 \mathrm{~b}$ ).

The subterranean clover/cocksfoot pasture has provided the most sheep liveweight gain of the five clover/grass mixtures in the 'MaxClover' experiment (Mills et al. 2008b). In contrast, over time, white clover has only been productive in the cocksfoot pasture during wetter than average late spring/summer growing seasons. The total mean annual $\mathrm{N}$ fixation that drove productivity of these two pastures over the first 7 years of 'MaxClover' (Table 2) was calculated from the clover 
DM yield (t/ha) data published by Mills et al. (2008a) and Mills \& Moot (2010, this volume) multiplied by 28 $\mathrm{kg} \mathrm{N} / \mathrm{t}$ clover DM reported in Fig. 3.

In broad terms New Zealand estimates for $\mathrm{N}$ fixation from ${ }^{15} \mathrm{~N}$ studies are similar to data from Australia. For instance, Peoples \& Baldock (2001) summarised a large number of Australian studies on $\mathrm{N}$ fixation and concluded that "on average close to $20-25 \mathrm{~kg}$ of shoot $\mathrm{N}$ is fixed for every tonne of legume herbage dry matter across a wide range of environments". In an experiment at Wagga Wagga, NSW, Dear et al. (1999) reported that subterranean clover in a phalaris (Phalaris aquatica) pasture fixed 23-34 kg N/t shoot DM biomass. This was consistent with the $28 \mathrm{~kg} \mathrm{~N}$ fixed/t legume DM from subterranean and white clover in our study and the $26 \mathrm{~kg} \mathrm{~N}$ fixed/t clover DM reported by Widdup et al. (2001) for Caucasian and white clovers.

While the average $\mathrm{N}$ fixation over 7 years (Table 2) was $81 \mathrm{~kg} \mathrm{~N} / \mathrm{ha} / \mathrm{yr}$ for subterranean clover and $46 \mathrm{~kg}$ $\mathrm{N} / \mathrm{ha} / \mathrm{yr}$ by white clover, this refers only to the fixed $\mathrm{N}$ in clover herbage above a stubble height of $25 \mathrm{~mm}$. A more comprehensive estimate would include the fixed $\mathrm{N}$ in stems under cutting height plus roots and nodules. Ledgard et al. (1985) suggested that the amount of $\mathrm{N}$ fixed in white clover herbage should be multiplied by 1.7 to give a more realistic estimate of total $\mathrm{N}$ fixation. This would increase the actual total amount of $\mathrm{N}$ fixed to $48 \mathrm{~kg} \mathrm{~N}$ fixed/t clover herbage. Similarly, it would increase the 7 year average $\mathrm{N}$ fixation to $138 \mathrm{~kg} \mathrm{~N}$ fixed/ $\mathrm{ha} / \mathrm{yr}$ for subterranean clover and to $78 \mathrm{~kg} \mathrm{~N}$ fixed/ha/yr for white clover. This is equivalent to an application of $300 \mathrm{~kg} / \mathrm{ha}$ of urea $(46 \% \mathrm{~N})$ to $\mathrm{CF} / \mathrm{Sub}$ pastures and 170 $\mathrm{kg}$ urea/ha to $\mathrm{CF} / \mathrm{Wc}$ pastures. At current prices $(\$ 620 / \mathrm{t}$ urea ex store, June 2010) this free $\mathrm{N}$ contribution has a monetary value of $\$ 186 /$ ha in CF/Sub and $\$ 105 /$ ha in $\mathrm{CF} / \mathrm{Wc}$ pastures. Assuming an average sheep and beef property is about 500 ha with half the farm in one of these two pastures this represents an $\mathrm{N}$ input, across 250 ha applied as urea, of $\$ 46500 / y r$ with subterranean clover based pastures and $\$ 26250 / \mathrm{yr}$ with the white clover/cocksfoot mix.

\section{Conclusions}

1. Fixed $\mathrm{N}$ was directly related to clover yield $\left(\mathrm{R}^{2}=0.96\right)$.

2. Subterranean clover and white clover fixed similar amounts of $\mathrm{N}(28 \pm 0.7 \mathrm{~kg} \mathrm{~N} / \mathrm{t}$ clover DM) when grown with cocksfoot under dryland conditions.

3. Subterranean clover fixed more $\mathrm{N}$ annually than white clover ( 81 versus $46 \mathrm{~kg} \mathrm{~N} / \mathrm{ha} / \mathrm{yr}$ ) because it was more productive when moisture is available in spring while white clover yield was limited by variable rainfall and high evapotranspiration in summer.

\section{ACKNOWLEDGEMENTS}

Financial assistance was from Beef + Lamb NZ and through the FoRST Pastoral 21 programme and Lincoln University.

\section{REFERENCES}

Brock, J.L.; Albrecht, K.A.; Tilbrook, J.C.; Hay, M.J.M. 2000. Morphology of white clover during development from seed to clonal populations in grazed pastures, Journal of Agricultural Science, Cambridge 135: 103-111.

Cox, J.E. 1978. Soils and agriculture of Paparua County, Canterbury, New Zealand. New Zealand Soil Bureau Bulletin 34.

Dear, B.S.; Cocks, P.S.; Peoples, M.B.; Swan, A.D.; Smith, A.B. 1999. Nitrogen fixation by subterranean clover (Trifolium subterraneum L.) growing in pure culture and in mixtures with varying densities of lucerne (Medicago sativa L.) or phalaris (Phalaris aquatica L.). Australian Journal of Agricultural Research 50: 10471058.

Edwards, G.R.; Lucas, R.J.; Johnston, M.R. 1993. Grazing preference for pasture species by sheep is affected by endophyte and nitrogen fertility. Proceedings of the New Zealand Grassland Association 55: 137-141.

Ledgard, S.F.; Simpson, J.R.; Freney, J.R.; Bergersen, F.J. 1985. Field evaluation of ${ }^{15} \mathrm{~N}$ techniques for estimating nitrogen fixation in legume-grass associations. Australian Journal of Agricultural Research 36: 247-258.

Mills, A.; Smith, M.C.; Lucas, R.J.; Moot, D.J. 2008a. Dryland pasture yield and botanical composition over 5 years under sheep grazing in Canterbury. Proceedings of the New Zealand Grassland Association 70: 37-44.

Mills, A.; Smith, M.C.; Moot, D.J. 2008b. Liveweight production from dryland lucerne, cocksfoot or ryegrass based pastures. In: Global Issues, Paddock Action. Proceedings of the 14th ASA Conference, 21-25 September 2008, Adelaide, South Australia. http://www.regional.org.au/au/asa/2008/concurrent/ managing pastures $/ 5830$ millsa.htm.

Mills, A.; Moot, D.J. 2010. Annual dry matter, metabolisable energy and nitrogen yields of six dryland pastures six and seven years after establishment. Proceedings of the New Zealand Grassland Association 72: 177-184.

Peoples, M.B.; Baldock, J.A. 2001. Nitrogen dynamics of pastures: nitrogen fixation inputs, the impact of legumes on soil nitrogen fertility, and the contributions of fixed nitrogen to Australian farming systems. Australian Journal of Experimental Agriculture 41: 327-346. 
Walker, T.W. 1996. Value of N-fixation to pastoral agriculture in New Zealand. White clover: New Zealand's Competitive Edge. Grasslands Research and Practice Series 6: 115-118.

Widdup, K.H.; Purves, R.G.; Black, A.D.; Jarvis, P.; Lucas, R.J. 2001. Nitrogen fixation by Caucasian clover and white clover in irrigated ryegrass pastures. Proceedings of the New Zealand Grassland Association 63: 171-175. 